\title{
STRATEGY PARADIGMS FOR THE MANAGEMENT OF QUALITY: DEALING WITH COMPLEXITY
}

\author{
IAN A. COMBE
}

London Metropolitan University

\section{GÜNTHER BOTSCHEN}

The Institute of Brand Logic

\begin{abstract}
Quality management is dominated by rational paradigms for the measurement and management of quality, but these paradigms start to 'break down', when faced with the inherent complexity of managing quality in intensely competitive changing environments. In this article, the various theoretical strategy paradigms employed to manage quality are reviewed and the advantages and limitations of these paradigms are highlighted. A major implication of this review is that when faced with complexity, an ideological stance to any single strategy paradigm for the management of quality is ineffective. A case study is used to demonstrate the need for an integrative multi-paradigm approach to the management of quality as complexity increases.
\end{abstract}

Key Words:

Quality Management, Complexity, Paradigms, Ideology,

Correspondence address:

Ian Combe

London Metropolitan University,

Stapleton House,

277 - 281 Holloway Road,

London N7 8HN

Tel: 02076072789

email: i.combe@londonmet.ac.uk 


\title{
STRATEGY PARADIGMS FOR THE MANAGEMENT OF QUALITY: DEALING WITH COMPLEXITY
}

\begin{abstract}
Quality management is dominated by rational paradigms for the measurement and management of quality, but these paradigms start to 'break down', when faced with the inherent complexity of managing quality in intensely competitive changing environments. In this article, the various theoretical strategy paradigms employed to manage quality are reviewed and the advantages and limitations of these paradigms are highlighted. A major implication of this review is that when faced with complexity, an ideological stance to any single strategy paradigm for the management of quality is ineffective. A case study is used to demonstrate the need for an integrative multi-paradigm approach to the management of quality as complexity increases.
\end{abstract}

Key Words:

Quality Management, Complexity, Paradigms, Ideology 


\section{Acknowledgements}

The authors would like to thank Andrea Baller, Martina Botschen, and the Editors and anonymous reviewers of the European Journal of Marketing, all of whom provided constructive comments on early drafts of this article. Addressing these comments has considerably improved the article.

\section{Biographical Details}

Ian Combe is a Senior Lecturer in Strategic Marketing at London Metropolitan University. His research interests lay in multi-paradigm views of strategy, strategic orientation and strategic flexibility.

Previously, he has held a position at Aston University, Birmingham, UK; and set up and managed two small companies in the service sector.

Günther Botschen is a Partner at 'The Institute of Brand Logic', Innsbruck, Austria. His consultancy interests are focused on strategic and operative brand management from an interdisciplinary perspective.

Previously, he has held positions as: Senior Lecturer, The Marketing Group, Aston University, Birmingham, UK; Lecturer, Department of Marketing, University of Innsbruck, Austria; Guest Professor at Tulane University New Orleans, US; and Visiting Lecturer, Group E.S.C. Brest, ESSCA Anger, edhec Nice, Group E.S.C. France. He has previously published in the European Journal of Marketing, Journal of Business Research, Marketing \& Psychology, Journal of International Business Studies, Journal of Euromarketing, and Marketing - Zeitschrift fuer Forschung und Praxis. 


\section{INTRODUCTION}

Quality management is dominated by rational paradigms for the measurement and management of quality. For example, quality is often measured by a rational functionalist approach that focuses on scientific reductionist study by dividing quality into constituent variables. This functionalist paradigm is inherent in the literature addressing the accreditation of quality and total quality management. It is also dominant in the service quality literature when discussing services blueprinting and forms the basis of the highly influential SERVQUAL model.

Authors such as Senge (1990) and Stacey (1995) have noted, however, that such rational paradigms start to 'break down' when faced with unpredictable and unstable conditions. In such circumstances, an ideological approach to strategy (see for example: Firat, 1985; Shrivastava, 1986; Venkatesh, 1985), that may not be appropriate for the environmental conditions, can have important consequences for companies and can lead to company failure (e.g. Barr, Stimpert, \& Huff, 1992).

There have been calls to address the limitations of ideological approaches to strategy, in order to provide more comprehensive explanations of management practice (e.g. Bourgeois, 1984; Ginsberg, 1984; Jemison, 1981). Comprehensive explanations are required to deal with complexity, such as those experienced when managing quality in technological arenas experiencing intensely competitive changing environments (Evans, 1991). These environments are becoming more dominant due to increasing competition in a more global information economy, and an increase in competitiveness promises to be a significant trend (Senge, 1990).

To deal effectively with complexity, managers are required to balance many issues to provide comprehensive strategies. To effectively manage these issues requires an 
understanding of the advantages and limitations of various strategy paradigms used for the management of quality. However, the practical implications of managing quality within specific paradigms, including the advantages and limitations of managing by these specific means, seem to be lacking within the literature. These advantages and limitations are discussed below to provide a more comprehensive view of strategies for the management of quality that is able to deal more effectively with complex situations. A review of these advantages and limitations suggests that in complex situations, an ideological reliance on any single strategy paradigm to manage quality is ineffective.

\section{THE STRATEGIC DEMANDS OF THE MANAGEMENT OF QUALITY}

Quality is a complex phenomenon based on perception by individuals with different perspectives on the quality of products and services. These perceptions have been built up through the past experience of individuals and consumption in various contexts. Consequently, quality encapsulates time and other contextual dimensions that add to the complexity of what is essentially a subjective evaluation of the quality of goods and/or services by the consumer. Strategies for managing quality, therefore, need to consider this inherent complexity and build complexity into quality management models. Any single paradigm provides a too narrow view to capture complexity, and the multi-faceted nature of reality (Burrell \& Morgan, 1979; Gioia \& Pitre, 1990). Therefore, to tackle the issue of complexity, a multi-paradigm approach to the management of quality is outlined here.

Several writers have noted that much of the management literature addressing the topic of quality is highly evangelical and universally prescriptive. This is especially stated in relation to the total quality management (TQM) literature (e.g. Drummond, 1995; Silvestro, 1998), with its roots in production of manufactured products. In contrast, the service quality literature is less universally prescriptive and benefits from more 
academically rigorous empirical research (Silvestro, 1998). Ideological views, however, are still present and dominant. For example, the rational functionalist view of strategy for the management of quality which suggests that service quality can be measured and managed through systematization (Levitt, 1972) is still influential. This view becomes ideological when implemented without any consideration of context, even when measurement is problematic and a more holistic view may be required. The core assumptions and beliefs underpinning this ideological view and the limitations of managing quality in this manner are given less prominence. We suggest that these limitations become much more pronounced as complexity increases.

\section{COMPLEXITY}

Complexity has started to receive considerable attention in the strategic management literature (e.g. Nutt, 1998; Parker \& Stacey, 1994; Senge, 1990; Stacey, 1991; Stacey, 1995; Stacey, 2000). Senge (1990) for example, discusses the distinction between two types of complexity; detail complexity and dynamic complexity. He suggests that the sophisticated tools of analysis, forecasting and planning are designed to deal with the first type of complexity, detail complexity, a type of complexity exemplified by a large number of variables.

These analytical tools are less effective when confronted by the latter type of complexity, dynamic complexity (Senge, 1990). The rational analytical view, according to Senge (1990), is less effective when dealing with forces that are in a state of dynamic change, because cause and effect are subtle and non-linear. This ineffectiveness of rational analysis and planning in certain situations is supported by empirical evidence that suggests that rational approaches to strategy are not effective in unstable environments. (Fredrickson \& Mitchell, 1984). 
In dealing with the dynamic type of complexity, obvious interventions produce nonobvious consequences, and even the same action can produce dramatically different effects over different time horizons (Senge, 1990). Support for this view is presented by Stacey (1995) when discussing the properties of organizations in terms of non-linear network feedback systems. Stacey (1995), suggests that these are the very organizational properties that complexity theory helps us understand. To Stacey (1995), organizations are clearly feedback systems because every time two humans interact, the actions of one person will have consequences for the other, requiring a further response. These feedback loops are non-linear because they are based on perceptions that lead to over- and underreactions (Senge, 1990).

Due to factors such as intangibility and perishability, managing quality in service settings is much more challenging than managing quality in product markets. It is even more challenging to manage quality in non-standardized relational service settings such as experienced in professional services. In this type of service, quality can be determined by the network that the company provides for a client, and these networks can be formal and centrally established, or informal and based on chance encounters of individuals with similar or different interests and expertise. The complexity of managing quality in this type of service is further increased if there is continuous change in the external environment due to intense competition and changing customer needs.

What seems to be missing from the literature addressing the management of quality to deal with this type of complexity, however, is any explanation of the advantages and limitations of different theoretical strategy paradigms. This explanation is required to help managers configure the advantages of various strategy paradigms to their particular needs and to be aware of their limitations. To this end, we highlight below the core assumptions and beliefs inherent in different theoretical strategy paradigms that can be used for the 
management of quality and propose integrating the advantages of various theoretical strategy paradigms in practice to deal with detail and dynamic complexity.

\section{COMPLEXITY AND CONNECTIVITY IN NETWORKS FOR QUALITY}

Network theory is widely discussed in the management literature. Here we focus on the connectivity in networks because the nature of the interaction will greatly influence service quality. If a standardized service is appropriate to increase quality, formal centrally established networks would seem appropriate to manage this standardization. In contrast, this formal network may not be appropriate for professional services especially where innovation and creativity may be important to the client. It is unlikely that rational planning of networks would be effective in these circumstances.

Problems arise in relation to service quality, however, when networks are allowed to form informally. Granovetter (1973) for example, reports that a greater variety of behaviour would be expected if informal ties between people are weak. This greater variety of behaviour may contribute to a client's perception of lower service quality, because of contradictory points of view expressed by members of the network group. If this occurs, the alternative is to encourage strong, more formal network ties to increase uniform behaviour. This behaviour may have more positive connotations for the client.

It may not be the strength or weakness of individual ties that influences the variety of behaviour in a network. Stacey (1995) suggests an alternative: the number of random ties that exist: a large number of connections suggesting weak ties, and a small number of connections suggesting strong ties. The study of informal networks suggests that limited connectivity across a network produces emergent order that remains stable for lengthy periods (Stacey, 1995), and this limited connectivity may be appropriate for relatively complex situations such as managing quality of relational services in stable external 
environments.

In changing unstable external environments a large number of random connections may be required, because this form of connectivity is more likely to produce a changing variety of emergent patterns of behaviour to match external change. In other words, a large number of random connections in a network is more likely to increase creativity. Thus, by encouraging more random connections in a network an organization is more likely to develop a highly flexible response to external environmental change. This approach, therefore, may be more appropriate for operating in highly competitive technological arenas.

Managing complexity is problematic. Stacey (1995) points out that the study of complexity in networks suggests order and patterns of behaviour that are emergent. The concept of spontaneous self-organizing emergent strategy may be, as Stacey (1995) contends, an integral property of organizations where informal networks exist. However, managing quality (or rather not managing) by this process may be frightening to managers due to the seemingly lack of any sort of control.

Senge (1990) offers an alternative solution to these systemic problems: that of the learning organization. This solution, at least, gives managers the hope that they may influence strategy if they follow Senge's (1990) advice and develop personal mastery and proficiency by learning. Learning about the systemic nature of organizations.

We contend that the emergent perspective and the learning perspective are important but partial solutions to the problems of managing complexity. We suggest, that an alternative solution to the problems articulated above: that of the multi-paradigm approach to build on the advantages of many perspectives. This alternative requires investigation and it is to this objective we now turn. Therefore, we incorporate both the solutions offered above 
into a multi-paradigm framework. We further argue that as complexity increases the need for a multi-paradigm approach to manage quality becomes more necessary.

\section{THEORETICAL STRATEGIES FOR THE MANAGEMENT OF QUALITY}

Theoretical strategies for the management of quality are no different from other strategies, in so much as they advance core assumptions and beliefs that largely go unquestioned due to their implicit nature. Questioning the appropriateness of theoretical strategies based on these core assumptions and beliefs is an important task for a critical analysis of the application of theory. Unless it is proposed that theories can be universally applied without question, which we do not, the contextual factors that deem that a theory may be effectively applied or not applied in a particular context should be investigated by research

To aid this investigation we use an integrational framework, grouping fifteen different strategy paradigms based on their implicit core assumptions and beliefs (see Combe, 1999). In developing his framework Combe (1999) has argued the theoretical case for integrating strategy paradigms into schools of thought at a philosophical level to aid empirical research. What is missing from this literature, however, are the practical implications of managing within specific paradigms, including the advantages and limitations of managing by these specific means. Additionally, the case for integrating the advantages of specific paradigms needs to be explored especially in the context of dealing with complexity. These issues are the focus of this current article.

The fifteen different theoretical strategy paradigms (Combe, 1999) are now outlined to distinguish between various strategies for managing quality and to highlight the core assumptions and beliefs associated with each. Rational paradigms; Developmental paradigms; Deterministic paradigms; Probabilistic paradigms; and Chaos paradigms are 
all outlined.

We suggest that a reliance on only one theoretical paradigm by its whole-sale acceptance by managers can lead to an uncritical ideology within an organization in relation to its strategy for the management of quality. An alternative argument is developed in this article: that the advantages of specific theoretical paradigms can be integrated in practice. We investigate the advantages and limitations of each so that these may be accepted and understood. We further suggest that managers should configure the advantages of different strategy paradigms to benefit the management of quality in their organizations, dependant on the contextual factors faced by the organization. The multi-paradigm view is further necessitated, we suggest, as complexity increases.

The main features of these theoretical strategy paradigms and the advantages and limitation for managing quality are as follows:

\section{Rational Paradigms}

These paradigms emphasise the human brain's capability to receive, organize and interpret information in an attempt to reduce and rationalize complexity to try to make sense of the environment. The main focus is on internal explanations by analysis of phenomena present in the environment, and to forecast these phenomena deliberately and proactively into the future. This type of approach to strategy can be found implicitly in many concepts, theories and perspectives. Four major paradigms are evident in the literature. These are:

\section{- The Rational Planning Paradigm}

The Rational Planning paradigm emphasises a hierarchically imposed, normative model of in-depth analysis, planning, implementation and control. This perspective has its roots in the writings of Fayol (1916/1949) and is dominant in much of the strategic 
management literature, such as the writings of Sloan (1963) and Ansoff (1965).

The rational planning paradigm may be appropriately applied to the management of quality in relatively complex and reasonably predictable environments (Fredrickson \& Mitchell, 1984; Fredrickson, 1985; Mintzberg, 1973). There are limitations, however, of managing quality by hierarchically imposed planning procedures and imposed views of quality from above. Problems can occur due to the enforcement of too much control that might not be appropriate for some contexts. In developing strategies for the management of service quality, a single approach to quality whatever the contextual setting, can lead to a lack of empowerment and alienation of the workforce. This lack of empowerment while seemingly appropriate to service settings that require mass standardisation, may not be appropriate to other settings such as professional services (Bowen \& Lawler, 1992).

Imposing a view of quality from above can be highly political, and a de-motivation of the workforce lower down in the organization may occur if workers have alternative views. For example, when Kentucky Fried Chicken (KFC) entered the Japanese market the local manager had full responsibility and empowerment to establish a KFC as a brand in this new environment. After establishing a strong position for KFC the headoffice imposed a new view of quality and reduced the power of the local manager. The latter resulted in de-motivation of the workforce and a change in the perception of quality. (Bartlett \& Goshal, 2000)

Another limitation of the rational planning paradigm is that it is focused mainly on predicting the future based on internal interpretations of the external environment, and these interpretations can be biased. Cognitive biases can be the result of culture (Hitt, Dacin, Tyler \& Park, 1997) and/or past experience (Ireland, Hitt, Bettis \& De Porras, 1987) and these biases can result in inaccurate predictions especially during periods of 
unpredictable change. In these situations rational planning can become ineffective.

\section{- The Modernist Paradigm}

The characteristics of Modernist thought in an organizational context, according to Alvesson and Deetz (1996), are the instrumentalization of people and nature by scientific thought. Thus there are three aspects of modernist thought that need to be considered in relation to the management of quality: people, nature and the possibility of instrumentalization or control.

Critical theorists such as Knights and Willmott (1987) have implied that strategies can be introduced for reasons of control and domination of the workforce, and therefore strategies for the management of quality may not be implemented purely for 'quality' improvements. However, in some organizations requiring a high degree of standardization, some control and dominance may be inevitable, but this control and dominance may break down in other contexts. For example, strategies for the management of quality dominated by the modernist paradigm are likely to break down in more complex relational service contexts, where empowerment of staff is required and standardization of service is of little value to customers.

Another problem with the modernist view is that it is anthropocentric because it focuses on the utilitarian value of products for the benefit of human lives by controlling nature through scientific technologies (Firat \& Shultz, 1997). Many products, however, are not purchased for their utilitarian value but for their symbolic value. Consequently, modernism's focus on the product and product attributes may be myopic, and this may have serious consequences for a company managing quality from this perspective.

Post-modernist theorists such as Alvesson and Deetz (1996) point out that modernism is based on a false premise of control, which is illusory. They also provide the most 
damning critique of modernist thought when they focus on the disastrous consequences for the environment and the alienation of the workforce when humans try to control nature and people for their own ends. An example of this is provided by the factory farming system which has a reputation of providing cost advantages in production through control of inputs such as food and living space, but at a very high environmental and ethical cost. Farm workers are alienated from nature rather than working in tune with it, because the system requires a focus on the maximization of output through cutting out the inefficiencies of nature. This farming system has also a reputation for a lack of perceived quality of output, because of its focus on quantity rather than quality.

\section{- The Functionalist Paradigm}

Taylor's (1911) reductionist view of scientific study aimed at maximum specialization is prevalent in the Functionalist paradigm. Weber (1947) promoted a similar rational specialist view within the bureaucratic organization by recognizing the growing need for experts with technical knowledge. The functionalist operational view is, according to Drummond (1995), also prevalent in accreditation of quality and the total quality management literature. Morgan (1986) also considers that Taylor's (1911) views can be still found today in the routinized operational focus of organizations such as McDonalds. Another example of functionalism can be found in large service organizations such as British Airways (BA) when they measure the quality of their service by breaking it down into many functional parts. As many as 350 aspects are measured at BA (Prokesch, 1995) in order to assess every aspect of the service in minute detail.

The management of quality within this paradigm is supposed to be efficiently achieved through formal methods of auditing, such as through procedures advanced by the accreditation of quality. A contradiction arises, however, because one form of total 
quality management, for example, implies a de-bureaucratization of the workforce through empowerment, but this is overlaid by an array of procedures that, by definition, re-deploys another layer of bureaucracy (Grint, 1997). Other approaches to the management of quality such as services blueprinting (Shostack, 1984) and quality function deployment (Hauser \& Clausing, 1988; Stauss, 1993) can also take a functionalist approach.

The bureaucratization of the management of quality is unlikely to be sustainable as a source of competitive advantage in certain highly competitive environments. Functional bureaucratic systems would have difficulty in coping with continuous changes in quality due to innovation and complex relational exchanges. Functional approaches can also divert the attention of managers to what is minutely measurable, rather than focusing on an holistic overview which may be a more accurate representation of the customers' perception of the quality delivered by the organization.

\section{- The Holistic Paradigm}

Follett's (1924) views, much influenced by Gestalt psychology, form the roots of a holistic view of strategy, where the focus is on an overview of the organization together with the advantages of human co-operation over human conflict. Thus, the holistic paradigm can be identified in the network literature, which addresses the issues associated with reducing risk by co-operation and forming relationships with others. It is also present in the stakeholder literature, which addresses the issues associated with balancing many demands on the organization.

The network literature is especially influential in relation to strategies for the management of quality, because manufacturing networks have been seen to increase quality especially in sectors such as the manufacture of motor vehicles. A visit to a Toyota motor 
manufacturing plant, for example, can indicate how close some networks can co-operate towards a common quality goal. The suppliers even relocate to be in close proximity to the manufacturer.

The holistic paradigm also implies that quality is best achieved through co-operation rather than imposed by hierarchies. Management through this paradigm therefore suggests an emancipation of the workforce through empowerment of the individual. This type of management seems highly appropriate for service companies where the level of standardization is low and encounter interaction high. From this perspective the management of quality is best achieved through a philosophical overview rather than a functional approach.

The main advantages of rational paradigms are that they address the issues of cognitive analysis and proactive management and choice within the firm, and rational accountability to other stakeholders. However, the organizational behavioural literature (e.g. Cyert \& March, 1963; Simon, 1957) argues that these advantages are based on the false premise of perfect rationality that does not exist due to cognitive limitations (Miller, 1956). Another limitation is that some degree of stability within the internal and external environments is required for the analytical aspects of rationalism to be effective. The increasing demands of hyper-competition within a global information economy suggest that this stability may be lacking at present.

\section{Developmental Paradigms}

These paradigms emphasise development through education and change both at an individual and organizational level. The emphasis is on the capacity of humans to learn from undertaking tasks such as production processes and planning of strategy, and to adapt by learning from past experience. The main focus is on the building of knowledge, 
resources and internal capabilities within the firm whether this is done proactively or a consequence of other activity.

Three major paradigms are evident in the literature. These are:

\section{- The Evolutionary (Lamarkian) Paradigm}

This evolutionary perspective is focused at the organizational level of analysis rather than the individual decision-maker, as it considers that adaptive evolution of organizations occurs through learning. Therefore, it is considered by some writers, such as Hannan and Freeman (1989), to be more applicable to organizational evolution than the alternative Darwinian theory that emphasises passive unchanging organisms being selected by the environment. At the level of the individual decision-maker, Lamarkian theory advances the hope that individuals can be leaders of evolution and adaptive change.

The literature on leadership of the management of quality seems dominated by universal generalisations from "gurus" and prescriptions based on autobiographical accounts (see Blois, 1992; for a critical appraisal). Learning from the experiences of chief executives autobiographical accounts may be useful, but regard must be taken of the contexts where certain styles of leadership may be appropriate.

\section{- The Process (Developmental) Paradigm}

The process developmental perspective focuses on both organizational and individual learning. This learning is brought about by undertaking production processes that enable learning curve effects, or management processes such as planning. Thus the focus of this paradigm is on so-called 'learning by doing' (Arrow, 1962). The developmental aspects can be emphasised by also experiencing and reflecting on the learning experience. An example is provided by the introduction of a process of continuous improvement in the Volkswagen Group, under the leadership of Ferdinand Piech. While working in small 
groups, employees were given the task of identifying processes and areas that could be improved to increase quality. After setting priorities of opportunities and immediately implementing them, employees reflected on these actions and were asked to apply this approach independently and in a continuous way.

The management of quality within the process developmental paradigm relies on continual improvement over the long term. Organizations can learn from encounters with customers; from complaints and the process of service recovery (Heskett, Sasser \& Hart, 1990). Virgin Atlantic Airways provides another example of the effective use of this type of process developmental strategy through their system of documentation, which allows them to turn complaints into service improvements and innovations (Denoyelle \& Larreche, 2000).

Organizations can also learn to be less bureaucratic in their approach to the management of quality, if bureaucratization is having a negative impact on the process of managing quality and perceptions of quality by customers.

\section{- The Resource-based View}

The critique of traditional economics developed by Penrose (1959) is considered by many writers (e.g. Wernerfelt, 1984) to be the historical influence of the resource-based view. This critique considers that traditional economic theory gives no notion to an internal process of development leading to cumulative movements of growth in firms. Thus for Penrose (1959) the firm was seen as a collection of productive tangible and intangible resources that provide services to production processes.

From a resource-based view, the focus of strategy for the management of quality should be on developing difficult to imitate resources. Consequently, from this perspective companies should differentiate through the use of difficult to imitate 'quality' resources 
such as the quality of innovation, design and service, because these are by definition more difficult for competitors to copy. An example of the difficulties that can be experienced by competitors when faced with this type of resource-based strategy is demonstrated by the very well established vacuum clearer manufacturers when competing with Dyson, due to the latter's focus on innovative design backed up by patents.

The main advantages of these paradigms lie in their focus on issues associated with adaptive evolution of the firm in a way that holds up the hope that management and the workforce can influence adaptive change, growth and long term survival. These paradigms also address the role of the individual in providing skills and knowledge that are useful to the firm, to the mobility of labour and to society at large.

Difficulties arise, however, from the never-ending capacity to absorb more information, knowledge, capabilities and other resources. The window of opportunity can close before knowledge and capabilities are built up. Thus, there is a need to balance the conflicting demands of exploration for more knowledge and capabilities, and the exploitation of existing knowledge and capabilities (Levinthal \& March, 1993; Penrose, 1959). Another potential problem is that devotees of these paradigms can be focused too much on internal developmental issues, and thus lose sight of changing customer needs externally.

\section{Determinist Paradigms}

These paradigms consider that events are determined by preceding events, therefore freedom of choice is illusory. The application of determinism in strategic management suggests that management has a passive role and is largely unable to influence change and long term survival. A more balanced view, however, might consider that although the external environment acts on internal company resources in a deterministic fashion, these resources have been built up through past experiences and learning by a non-Darwinian 
process. There are many deterministic ways of thinking implicit within the strategic management literature. For example, the concept of a life cycle and the notion that strategies should be linked to different stages in that life cycle, implies a form of determinism. One major deterministic paradigm has generated most debate, however, and is outlined here.

\section{- The Evolutionary (Darwinian) Paradigm}

Darwinian theory suggests that the origin of adaptations lies in natural selection acting on hereditary variations that are in their origin non-adaptive (Maynard Smith, 1975). The natural environment is the adaptive force acting on many variations of organisms, only the organisms that fit with the environment survive. Therefore the external environment is the ultimate selecting force and the individual does not possess the capacity to adapt itself. In an organizational context this view of evolution considers that environmental change, resource specificity and structural inertia (Hannan \& Freeman, 1984) emphasise selection. This view is prevalent in the population ecology literature.

From this perspective, strategy for the management of quality is of little value, because the external environment ultimately determines success of organizations. In the age of the computer, a quality mechanical typewriter is unlikely to be purchased. Therefore, from this perspective strategies for the management of quality should not be considered in isolation, but integrated with corporate and business strategies to provide a wider picture. Furthermore, due to resource specificity and structural inertia even strategies at another hierarchical level may not be effective in response to change. The answer to these problems may be to try to maintain organizational flexibility (Evans, 1991; Sanchez, 1995), so that the company is responsive to changing environments.

The main advantage from this perspective is that there is a comprehension of the influence 
of links between the external environment to the internal environment. The disadvantages are that it undermines the effectiveness of rational choice, learning and proactive development by management.

\section{Probabilistic Paradigms}

These paradigms are based on the importance of the dynamic interactive nature of the business environment so that modification of strategy by interaction with other factors is emphasised. Externally these factors may be due to changing competitors offerings and changing customer needs, whereas internally strategy is realized through interaction with cultural beliefs and political forces that may cause barriers to change. This interaction means that both strategies for the management of quality, and indeed, the concept of quality itself, both need to take account of interactive contingent effects.

Five major probabilistic paradigms are present in the literature:

\section{- The Ecological Paradigm}

The focus of the ecological paradigm is on the dynamic and interactive nature of competition for external resources. Much of the empirical research utilizing this paradigm in an organizational context, focuses its activity at the population or industrial level (e.g. Carroll, 1985; Boeker, 1991; Ingram, 1996). This approach has been useful for its longitudinal evolutionary perspective to indicate variables influencing founding and failure of organizations. Further work developing the implications of the concepts of competitive exclusion and niche width at the organizational level to aid strategic management could be a suggested way forward (see Baum, 1996; for a thorough review).

The management of quality within the ecological paradigm suggests that organizations should pursue a differentiation strategy from competitors to exploit a niche before a competitor fills it. To achieve this companies may use the concept of positioning to 
identify a niche and to differentiate themselves from competitors. For example, Virgin Atlantic Airways differentiated itself successfully as a service provider with great customer value within the highly competitive airline industry by focusing on three differentiation aspects: innovative surprises; entertainment $\&$ fun; and service recovery (Denoyelle \& Larreche, 2000).

Due to the contingent nature of strategy, being based on the availability of niches left by competitors, the timing of entry of new products and services is also important from this ecological perspective.

\section{- The Process (Emergent) Paradigm}

March and Simon (1958) and Lindblom (1959) were amongst the first to critique the purely rational approach to policy formulation by suggesting that it assumes "perfect" intellectual capacities; sources of information; and time and money. These factors are always limited to a greater and lesser degree. The complexity of the problem was for Lindblom (1959) the key factor in determining the limited usefulness of the rational approach. Lindblom's (1959) suggested response was an incremental view in which decision making is remedial, proceeding in small steps not too far from the status quo. This does not necessarily imply that decision making should be merely tactical, as this approach can be led by a rational strategy that is adaptive (Mintzberg, 1973) and incremental (Quinn, 1980). This perspective is also associated with the manager addressing multiple conflicting goals, and a political dimension to decision making (Mintzberg, 1973) with associated barriers to change. (See Wilson, 1992; for an overview of planned versus emergent change) 
From the process (emergent) perspective management needs to consider two main issues concerning the implementation of strategies for the management of quality. The first is the political implications of changes in product/service quality, because this issue can be controversial and can lead to an alienation of staff. This alienation may be especially acute if, for example, an organization known for high quality deems it necessary to reduce quality and 'go down market'.

The second is the political implications of changes in management processes. For example, Carlzon (1987) raises the problem of devolving responsibility for quality to one group at SAS airlines, which consequently made another group feel threatened by the loss of authority.

The process emergent paradigm considers that hierarchically imposed plans for the management of quality are likely to be modified by interaction with political forces within organizations. Consequently, strategies emerge by this interaction. This emergent strategy may not necessarily be a problem for management, because a strategy may emerge and be implemented that takes account of contextual factors within organizations. More effective strategies for managing quality within the context of organizational reality may result.

\section{- Game Theory}

According to Camerer (1991), Game Theory is the analysis of rational behaviour in situations involving interdependence of outcomes. Implicit in Game Theory is the presence of some degree of rationality, adherence to rules of the game, some knowledge of the other players and convergence to equilibrium. Whilst some might question some of these implicit assumptions, Game Theory holds up the hope of behavioural prediction by modelling how others are likely to play the game. Probabilistic prediction of competitors' responses within a dynamic changing environment would inevitably be very welcomed by 
many strategic decision-makers.

From this perspective, managers of quality should advance 'follow the leader' strategies to ensure equilibrium with their main competitors, and build a reputation for retaliation and holding grudges to ensure 'mutually assured destruction' (MAD) (see Whittington, 1993). For example, the retail chains SPAR and Billa (an Austrian associate of the German REWE Group) continually monitor the pricing strategy of the other to ensure equilibrium. This is required because a change to the price of any part of the product assortment is a signal to consumers of the best value retailer.

\section{- The Behavioural Paradigm}

In achieving rational cognitive explanations for behaviour, research has tended to minimize the effects of the settings in which the behaviour occurs (Foxall, 1992). Thus the behavioural perspective has received less attention. This paradigm, also associated with the behaviourist writings of B. F. Skinner, attributes action to external factors to the individual such as reward and punishment stimuli in a probabilistic fashion. Thus the behavioural perspective is the antithesis of cognitivism (Foxall, 1992).

The management of quality within the behavioural paradigm suggests an interactive trial and error strategy based on positive and negative feedback from consumers. Kentucky Fried Chicken's market entry strategy into Japan can be considered to be based on interactive trial and error, because most of the highly standardized products and processes had to be adapted towards the unique Japanese customer and environmental requirements. The main advantage of trial and error strategies are that the chosen strategy should be highly adapted to present customer needs. The main disadvantage is the cost of too many trials.

\section{- The Social Contextual Paradigm}


Whittington (1993) argues strongly against considering strategy out of context because organizations are socially embedded and therefore strategies need to be studied in their social, economic and political context.

This paradigm suggests that universal prescriptions for the management of quality are unlikely to be effective, because they lack the context that made them effective in a different culture. From this social embedded perspective it is no accident that Italian and French design and fashion companies are the leading providers of high quality luxury products, accessories and haut couture, and the Moët Hennessy Louis Vuitton Group is the world leading manufacturer and supplier of 50 top luxury brands. (Arnault \& Wetlaufer, 2002).

Another example of the social embeddedness of companies can be seen through the exploitation of the unique apprenticeship system in the German speaking area, which allows them to differentiate on the manufactured quality of components, tools and machinery.

The main advantage of Probabilistic paradigms are that they recognize the issues of interaction and exclusion in a dynamic competitive environment. The recognition that a company is not isolated from the moves of its competitors, the behaviour of consumers or its social context is important. These paradigms also incorporate environmental complexity and speed of reaction to customer needs and competitive moves, which are consistent with the relentless pressures on firms in competitive markets. While these paradigms highlight the dynamic interactive nature of competitive business, they can lack the analysis of Rational paradigms and the long-term view of Developmental paradigms. These could be considered to be the main disadvantages of probabilistic paradigms.

\section{Chaos}


These paradigms consider that management has to address complexity and unpredictability. An application in a management context can suggest that the consumer is unpredictable and fickle therefore rational strategy is of little value. Whereas another paradigm emphasises the inter-connectedness of phenomena so that a small change in one area can produce amplified chaos elsewhere. To overcome chaos organizations can focus internally on responses to unpredictability such as creative individualism, reactive speed and organizational ideology, rather than traditional ideology.

\section{- The Post-modernist Paradigm}

This paradigm seems to emphasise the chaotic elements of business rather than directly applying Chaos Theory. Therefore, there is a focus in the post-modernist marketing literature on fragmentation of societies and global individualism. Consumers are considered to be unpredictable, often subscribing to multiple highly contradictory value systems and lifestyles (Firat, Dholakia \& Venkatesh, 1993). Strategy in these circumstances could involve merging the customer and the producer. Therefore, writers, such as Firat and Shultz (1997), promote the trend towards customization to individual's self images, and the relationships and partnerships required to offer a customizing process, rather than a particular product.

The management of quality within the post-modernist paradigm has to contend with these changes. From this perspective the features of products are less important than the images conveyed by them. Thus, customers purchase a pair of Nike training shoes, for example, not so much for their utilitarian value, but for their symbolic value (Crowther \& Combe, 1999). Therefore from a post-modernist perspective, strategists need to re-consider the nature of quality. In an era of global hyper-competition symbolic quality seems to be more important than utilitarian product quality. 


\section{- Chaos Theory}

According to writers such as Stacey (1991) business systems model chaotic systems based on non-linear amplifying feedback mechanisms that are extremely sensitive to initial conditions. At a critical point, equilibrium is punctuated by chaos. From this perspective managers need to recognize the inter-connectedness of organizational processes, so that there is an understanding that a decision taken to alter one process can cause amplified chaos elsewhere. However, as patterns of order are intertwined with disorder it is possible to predict some aspects of the future over the short term.

The implications for the management of quality are twofold. The first, is to recognize this inherent long-term unpredictability and to consider the systemic nature of organizational reality. This systemic nature suggests that managers should not expect control and should not separate the management of quality from other management issues, because they are all inter-connected. Senge (1990) provides a good example of these effects in his management game, which highlights the inter-connectedness and built in delay inherent in a supply chain. A small increase in orders at the retail level encourages managers to overorder products from the wholesaler further up the supply chain so that demand cannot be met. Managers, it seems, do not anticipate the delay in supply that is built into the system and the inter-connectedness of their decisions to others also ordering from the same supplier.

The second, from a management perspective, is to focus on relatively stable aspects of the environment and the prediction and planning of strategy over the short-term only.

The main advantages of Chaos paradigms are that they recognize the issues of the interconnectedness of organizational processes, together with the issues of unpredictable change that are especially pertinent as organizations contend with a move from national 
industrial economies to global information economies. The main difficulties lie in developing solutions to deal with different forms of chaos. As Chaos Theory predicts, change at the societal or organizational level is not continually chaotic, but can enter into more predictable periods. In these periods other paradigms may be more helpful.

Table I, below, lists the theoretical strategy paradigms and summarises the implications for the management of quality.

take in Table 1

\section{INTEGRATING THE ADVANTAGES OF STRATEGY PARADIGMS FOR THE MANAGEMENT OF QUALITY}

The previous discussion highlighted advantages and disadvantages of the various strategy paradigms that can be applied to the management of quality. It also suggests that in practice, organizations cannot rely on only one paradigm to effectively manage quality, because any one paradigm will possess limitations as well as advantages. These limitations need to be addressed from the perspective of alternative strategy paradigms.

The advantages and limitations of strategy paradigms highlighted in this article suggest that the context is the important consideration when deciding which paradigms may be more appropriately applied to the management of quality. Thus important contextual issues such as the level of external environmental change; the nature of the organization; the nature of the market/s served; the nature of the industry; and the level of competition, will deem some strategy paradigms more appropriate than others. Consequently, managers need to integrate various configurations of strategy paradigms to benefit from their various advantages.

We suggest that as complexity increases there will be a greater need to consider a multi- 
paradigm integrationist view of strategy for the management of quality. Complexity is inherent in the management of quality in some contexts, such as managing relational services in intensely competitive changing environments. We therefore suggest that a multi-paradigm approach would be especially useful in dealing with the management of quality in these circumstances. If a manager has to address a multitude of problems, changing the mind-set from one single strategy paradigm to another single paradigm is unlikely to be an effective solution.

\section{THE IMPLICATIONS FOR RESEARCH}

An integrative multi-paradigm approach to strategy for the management of quality raises several implications for research. Firstly, we highlight the implications for strategy practice by reference to a case study involved in managing quality in a highly competitive technology arena. The case study was chosen to highlight the issues of managing quality in increasing unpredictable and complex environments. This is achieved in the company: Industrial Technical Flooring (ITF) Ltd. because it has historically operated in a very predictable stable environment, but was suddenly faced with unpredictability and increasing complexity brought about by recession.

Secondly, we highlight the need for researchers to study complexity through a multiparadigm approach, especially as complexity increases. The case study raises implications for research methodology to investigate multiple paradigms in a practical setting. The original study, undertaken by one of the authors, focused on strategic marketing within the rational planning paradigm. The details highlighted in the case were brought to light because the rational planning approach to strategy was found to be ineffective in the context outlined below. The reasons for the failure were explored though in-depth semistructured interviews with all the directors and senior managers of the company. However, 
this exploration was not initially planned. Therefore, to be more prepared in future to explain practice from a multi-paradigm perspective, we briefly suggest some research methods that may be appropriate for investigating different strategy paradigms within organizations.

\section{A Case Study: Integration of strategy paradigms in practice}

Industrial Technical Flooring (ITF) Ltd. (fictitious name) is a medium sized service company involved in the supply and fitting of specialist raised flooring for computer suites and offices where cabling needs to be hidden but where access may also be required if problems occur.

Evidence of the existence of Rational paradigms, especially rational planning, were evident by the existence of detailed forecasting and planning documentation which were relied upon by executives in making decisions. This reliance on analysis and planning may be largely due to the predictable nature of the market served. The company's flooring service was required near the end of the building cycle, therefore the amount of office space under construction could be accurately predicted well in advance. All four of the directors suggested that the average time taken from the start of office construction to the need for flooring was approximately two years. Thus the largely predictable external conditions allowed the use of forecasting techniques and the setting of broad objectives for managers to meet within an annual planning cycle.

Quality was managed within the rational planning paradigm by hierarchically imposing the managements' view of quality on the workforce. Due to the stability and predictability of the external environment it is likely that the management view of

quality was a reasonably accurate representation of their customers view. Another 
rationale for the quality initiative emerged, however, when the directors admitted that one of the positive consequences of initiating quality procedures was to control staff and to change work practices. Thus the rational planning and modernist paradigms provide the major theoretical explanations for the strategy to manage quality within the company.

Several Developmental paradigms were evident in the company's activities. The management stated that they had learned to become less formalized in their planning process because formalization, with fixed ridged objectives and budgets, was found to be ineffective in the past. The company and its direct competitors undertook work for a reasonably small number of large construction companies, therefore gaining or losing one or two of these jobs would render formalized budget forecasts totally inaccurate. They had learned to be more proactive and flexible in planning by chasing jobs, especially large prestigious jobs, and phoning up for feedback if they were unsuccessful.

The learning curve effects with regard to the flooring services were not highlighted in the study, but the directors considered that they had learned the differences in service needs of American and British customers and that this knowledge had helped them gain repeat business.

Quality was not initially managed within ITF Ltd. from a developmental perspective. However, the sales and marketing directors admitted that the hierarchically imposed strategy for the management of quality was not initially effective, "because shop floor workers could not understand why certain quality procedures were being enforced". They admitted that, in hindsight, it would have been better to achieve more consensus by consulting the workforce and developing educational programmes to explore the 
rationale for managing quality.

Aspects of Deterministic paradigms could be found in the planning system and the simple hierarchical organizational structure, because these seemed to be determined by predictability within the industry. The international marketing strategy highlighted another deterministic effect, because it was initially largely determined by the onset of the recession in the British office construction industry in the early 1990's. The general effects of which, to the company, were accurately predicted by monitoring new construction starts. The recession also largely determined the need for product re-positioning because it was considered that the company would have to discount to large customers in the new more difficult trading conditions.

These recessionary forces influenced the management of quality because the company felt it necessary to reduce prices, and thereby reduce the quality of the tangible product (flooring) and staffing levels, to fit with the new economic conditions. This strategy, based on rational planning but led by deterministic forces, was highly successful because the company was able to undercut its competitors by reducing costs and prices and this resulted in a large increase in market share leading up to, and during, the recession.

Probabilistic paradigms could also be identified. While the need to internationalize could be attributed to deterministic effects, the choice of target countries could be attributed to probabilistic effects. The company firstly targeted Germany as the "best" market for their product. As a result of the initial market research, however, they found that there were several German companies offering a similar high quality service and that there was also a lot of competition down market. They therefore decided to initially target Spain as there was "more of a gap in the market for a 
company with their skills". Due to the nature of the competition in Spain they found that they had to reduce the quality of their services to be competitive.

Thus information from market research, experience of operating in a new European market, together with new conditions in the domestic market, all confirmed the need to reposition 'down market' and reduce quality of product and prices. Thus the ecological paradigm provides the dominant explanation for the strategic management of quality within the international arena, because this strategy was largely led by interactive concepts such as positioning, based on competitive exclusion and finding a niche.

An emergent probabilistic effect can be identified when studying the barriers, put up by the established staff, to the implementation of strategies to manage quality. Thus in some respects a strategy to manage quality has emerged in the company in response to the problems resulting from the hierarchical imposition of quality from above, using a rational hierarchical approach

The issues important to Chaos paradigms were largely mitigated by the predictable nature of the market served. However, when the external conditions became more unpredictable the company focused internally on re-designing their product and service so that they could offer lower price and lower quality. Through a focus on creative design and reactive speed, the company was able to "steal" market share from competitors in the new highly competitive recessionary conditions. The case study as a whole highlights the complexity and inter-connectedness of management issues and problems so that quality itself should be considered from a systemic perspective. 
The case highlights the integrated nature of strategy problems and strategic decisions with special reference to the management of quality issues. Attempting to investigate and explain these issues from only one paradigm would have resulted in a limited understanding of the complexity present. The case also highlighted the problems associated with the assumption that quality can be managed from one perspective. ITF Ltd. attempted to manage their quality solely from a rational planning perspective. They found, however, that this approach was not particularly effective even within a stable largely predictable industry. Theoretically, these are the very conditions that are supposed to be ideal for this rational approach to be most effective.

An in-depth understanding incorporating other perspectives has indicated that the company also managed their quality using other strategy paradigms, although the company itself may have been unaware of doing so. These strategy paradigms have additional advantages such as flexibility and co-ordination of effort that may help companies to effectively manage their quality within different trading environments.

\section{The Implications for Research Methods}

The above case study demonstrates, that multiple paradigms of strategy already exist in management practice. Consequently, a reductionist study working within a single research paradigm will not illuminate what is happening in practice.

Multiple research methods would be required to supplement the in-depth interviewing technique used in the case study. For example, experimental methods may be required to uncover the strategy paradigms currently used by managers from a cognitive perspective. Theorists suggest that these methods are necessitated to uncover the manager's 'theories in use' (Argyris and Schön; 1974; Prahalad and Bettis, 1986), to uncover the strategy paradigms that actually govern behaviour, because these cannot be obtained simply by 
asking for them. The well-known problems associated with the use of experimental methods, however, suggest that other more 'real life' methods are also required.

Investigating issues within specific strategy paradigms suggest further problems for researchers. For example, developmental strategies represent unique research problems because competitively superior resources and the capabilities to deploy them are difficult for managers to identify. Developmental phenomena also have a long term focus necessitating longitudinal research methods. Probabilistic emergent strategies have been successfully investigated by these means (e.g. Mintzberg \& Waters, 1982), and the practical difficulties of this type of study are well understood. Inevitably, due to the time consuming nature of these studies this approach may continue to be less common than cross-sectional studies. However, investment in time is required to fully understand developmental and emergent phenomena.

Stacey (1995) reviews the research methods most applicable to investigating complexity and also suggests that cross-sectional studies will not capture phenomena important in non-linear systems. To fully understand complexity from within the system, Stacey (2000) argues for a social constructionist, reflexive approach, and longitudinal research through participant enquiry methods.

Investigating other issues important for managing quality within other strategy paradigms raises other methodological problems. For example, to uncover phenomena important in a Post-modern paradigm, such as symbolic quality, interpretive methods such semiotics can be used (e.g. Christensen \& Askegaard, 2001).

The multifaceted nature of these problems, suggests that a multi-disciplinary research team may be required to fully investigate multiple paradigms of strategy in a large 
complex company. However, individual researchers can be effective if they do not have an ideological stance to research methods and are prepared to use multiple methods.

\section{CONCLUSION}

It has been suggested in this article, that strategy paradigms should not be applied uncritically to the management of quality. The various theoretical strategy paradigms employed to manage quality were discussed and the advantages and limitations of these paradigms for managing quality were highlighted. In the case study we highlighted the limitations of an ideological approach to strategy especially as complexity increases. We also highlighted the inter-connectedness of management issues and problems to indicate the sort of complexity that strategies for the management of quality have to deal with.

Many writers have advanced alternative strategy paradigms to deal with different forms of complexity. For example, Ansoff (1965) has advanced the rational planning paradigm and Shostack (1987) has suggested the fuctionalist paradigm to deal largely with detail complexity. Other writers have suggested alternative strategy paradigms to deal with more dynamic type of complexity. Senge (1990) for example, has made a strong case for the developmental learning paradigm, whereas Stacey (1995) has put forward the process emergent paradigm. We contend that these offer partial solutions for managing quality in complex situations. Furthermore, we have advanced the 'complexity debate' by explaining the multi-paradigm approach that incorporates and builds on the alternatives presented by other theorists. We contend that this multi-paradigm approach offers benefits in comprehensiveness in strategies for the management of quality.

\section{REFERENCES}

Alvesson, M. \& Deetz, S (1996), Critical Theory and Postmodernism Approaches to Organizational Studies, In: S.R. Clegg, S. Hardy \& W.R. Nord (Eds.), Handbook of Organizational Studies, Sage, pp.191-217.

Ansoff, H.I. (1965), Corporate Strategy: An Analytical Approach to Business Policy for 
Growth and Expansion, McGraw-Hill.

Argyris, C. \& Schön, D.A. (1974), Theory in Practice: Increasing Professional Effectiveness, Jossey-Bass.

Arnault, B. \& Wetlaufer, S. (2002) Das perfekte Paradox von Star-Marken, Harvard Business Manager,Vol.24, No.3,pp.20-29.

Arrow, K.J. (1962), The Economic Implications of Learning by Doing, Review of Economic Studies, Vol.29, pp.155-173.

Barr, P.S., Stimpert, J.L. \& Huff, A. S. (1992), Cognitive Change, Strategic Action, and Organizational Renewal, Strategic Management Journal, Vol.13,pp.15-36.

Bartlett, Ch.A. \& Ghoshal S. (2000) Transnational Management $3^{\text {rd }}$. Ed., McGraw Hill Higher Education.

Baum, J.A.C. (1996), Organizational Ecology, In: S.R. Clegg, S. Hardy \& W.R. Nord (Eds.), Handbook of Organizational Studies, Sage, pp.77-114.

Blois, K. (1992) Carlzon's 'Moments of Truth': a Critical Appraisal, International Journal of Service Industry Management, Vol.3, Iss.3, pp.5-17

Boeker, W. (1991), Organizational Strategy: An Ecological Perspective, Academy of Management Journal, Vol.34, No.3, pp.613-635.

Bourgeois, L.J. III (1984), "Strategic Management and Determinism", Academy of Management Review, Vol.9,No.4, pp.586-596.

Bowen, D.E. \& Lawler III, E.E. (1992), The Empowerment of Service Workers: What, Why, How and When, Sloan Management Review, Vol.33, No.3, pp.

Burrell, G. \& Morgan, G. (1979) Sociological Paradigms and Organizational Analysis: Elements of the Sociology of Corporate Life. Heinemann.

Camerer, C.F. (1991), Does Strategy Research Need Game Theory? Strategic

Management Journal, Vol.12, pp.137-152.

Carlzon, J. (1987), Moments of truth, Ballinger Publishing.

Carroll, G.R. (1985), Concentration and Specialization: Dynamics of Niche Width in Populations of Organizations, American Journal of Sociology,Vol.90,No.6, pp.1262-1283.

Christensen, L.T. \& Askegaard, S. (2001) Corporate identity and corporate image revisited: A semiotic perspective, European Journal of Marketing, Vol.35,No.3/4,pp.292315.

Combe, I.A. (1999), Multiple Strategy Paradigms: An Integrational Framework, Journal of Marketing Management, 15, pp.341-359.

Crowther, D.E. \& Combe, I.A. (1999), Marketing 'Cool Britannia': Implications for Organisations, British Academy of Management Annual Conference, Sept. 1999, Working Paper; Abstract Published in Conference Proceedings, Vol.II,pp1182.

Cyert, R.M. \& March, J.G. (1963), A Behavioral Theory of the Firm, Prentice-Hall Inc.

Denoyelle, P. \& Larreche, J-C (2000) Virgin Atlantic Airways - Ten Years After, in: Valerie A. Zeithaml and Mary Jor Bitner, Services Marketing, $2^{\text {nd }}$. Edition, 2000, McGraw-Hill Higher Education

Drummond, H. (1995), Beyond Quality, Journal of General Management, Vol.20, Iss.4, Summer, pp.68-77.

Dutton, J.E. \& Jackson, S.E. (1987), Categorizing Strategic Issues: Links to Organizational Action, Academy of Management Review, Vol.12,No.1,pp.76-90. 
Evans, S. (1991), Strategic Flexibility for High Technology Manoeuvres: A Conceptual Framework, Journal of Management Studies, 28:1,pp.69-89.

Fayol, H. (1916/1949), Administration Industrielle et Générale, Dunod; Trans. Sir Isaac Pitman and Sons.

Firat, A.F. Dholakia, N. \& Venkatesh, A. (1993), Marketing in a Postmodern World, European Journal of Marketing, Vol.29, No.1, pp.40-56.

Firat, A.F. \& Shultz, C.J. II. (1997), From Segmentation to Fragmentation - Markets and Marketing Strategy in the Postmodern Era, European Journal of Marketing, Vol.31, Nos.3/4, pp.183-207.

Firat, A.F. (1985), Ideology VS. Science in Marketing, In: Changing the course of marketing, (Eds: Dholakia, N. \& Arndt, J.), JAI Press, Greenwich, pp.135-146.

Follett, M.P. (1924), Creative Experience, Longmans, Green \& Co.

Foxall, G.R. (1992), The Consumer Situation: An Interactive Model for Research in Marketing, Journal Of Marketing Management, Vol.8, pp.383-404.

Fredrickson, J.W. (1985), Effects of Decision Motive and Organizational Performance Level on Strategic Decision Processes, Academy of Management Journal, Vol.28,No.4,pp.821-843.

Fredrickson, J.W. \& Mitchell, T.R. (1984), Strategic Decision Processes: Comprehensiveness and Performance in an Industry with an Unstable Environment, Academy of Management Journal, Vol.27,pp.399-423.

Ginsberg, A. (1984), "Operationalizing Organizational Strategy: Toward an Integrative Framework”, Academy of Management Review, Vol.9,No.3,pp.548-557.

Gioia, D.A. \& Pitre, E. (1990), Multiparadigm Perspectives on Theory Building, Academy of Management Review, Vol.15,No.4, pp.584-602.

Granovetter, M.S. (1973), The Strength of Weak Ties, American Journal of Sociology, 78,pp.1360-1380.

Grint, K. (1997), TQM, BPR, JIT, BSCs and TLAs: Managerial Waves or Drownings?, Management Decision, Vol.35, Issue 10, pp.731-738.

Hannan, M.T. \& Freeman, J. (1984), Structural inertia and organizational change, American Sociological Review, 49, pp.149-164.

Hannan, M.T. \& Freeman, J. (1989), Organizational Ecology, Harvard University Press.

Heskett, J.L., Sasser, W. E. Jr. \&. Hart, C.W.L (1990), Service Breakthroughs, The Free Press, New York.

Hauser J. R. \& D. Clausing (1988), The House of Quality, Harvard Business Review, May - June, pp.63-73.

Hitt, M.A. \& Tyler, B.B. (1991), Strategic Decision Models: Integrating Different Perspectives, Strategic Management Journal, Vol.12, pp.327-351.

Hitt, M.A., Dacin, M.T., Tyler, B.B. \& Park, B. (1997), Understanding the Differences in Korean and U.S. Executives' Strategic Orientations, Strategic Management Journal, Vol.18.2, pp.159-167.

Hrebiniak, L.G. \& Joyce, W.F. (1985), Organizational Adaptation: Strategic Choice and Environmental Determinism, Administrative Science Quarterly, 30,pp.336-349.

Ingram, P. (1996), Organizantional Form as a Solution to the Problem of Credible Commitment: The Evolution of Naming Strategies among U.S. Hotel Chains, 1896-1980, Strategic Management Journal, Vol.17, pp.85-98. 
Ireland, R.D., Hitt, M.A., Bettis, R.A. \& De Porras, D.A. (1987), Strategy Formulation Processes: Differences in Perceptions of Strength and Weaknesses Indicators and Environmental Uncertainty by Managerial Level, Strategic Management Journal, Vol.8, pp.469-485.

Jackson, S.E. \& Dutton, J.E. (1988), Discerning Threats and Opportunities, Administrative Science Quarterly, Vol.33,p p.370-387.

Jemison, D.B. (1981), “The Importance of an Integrative Approach to Strategic Management Research”, Academy of Management Review, Vol.6, No.4,pp.601-608.

Kiesler, S. \& Sproull, L. (1982), Managerial Response to Changing Environments: Perspectives on Problem Sensing from Social Cognition, Administrative Science Quarterly, 27, pp.548-570.

Knights, D. \& Willmott, H.C. (1987), Organizational Culture as Management Strategy: A Critique and Illustration from the Financial Services Industry, International Studies of Management and Organization, Vol.17, No.3, pp.40-63.

Kuhn, T. S. (1970), The Structure of Scientific Revolutions, Second Edition, University of Chicago Press.

Levinthal, D.A. \& March, J.G. (1993), The Myopia of Learning, Strategic Management Journal, Vol.14, pp.95-112.

Levitt, T. (1972), Production-line Approach to Service, Harvard Business Review, Vol.50, No.5, pp.41-52.

Lindblom, C.E. (1959), The Science of Muddling Through, Public Administration Review, 19, pp.79-88.

March, J.G. \& Simon, H. (1958), Organizations, Wiley.

Maynard Smith, J. (1975), The Theory of Evolution, Penguin.

Miller, G.A. (1956) The Magic Number Seven Plus or Minus Two: Some Limits to our Capacity for Processing Information, Psychology Review, 50,pp.81-97.

Mintzberg, H. \& Waters, J.A. (1982), Tracking Strategy in an Entrepreneurial Firm, Academy of Management Journal, Vol.25,No.3,pp.465-499.

Mintzberg, H. (1973), Strategy-Making in Three Modes, Californian Management Review, Winter, Vol.XV1, No.2, pp.49-53

Morgan, G. (1980), Paradigms, Metaphors, and Puzzle Solving in Organizational Theory, Administrative Science Quarterly, 25,December, pp.605-622.

Morgan, G. (1986), Images of Organization, Sage.

Nutt, P.C. (1998), How Decision Makers Evaluate Alternatives and the Influence of Complexity, Management Science, Vol.44,No.8,pp.1148-1166.

Parker, D \& Stacey, R. (1994), Chaos, management and economics, The Institute of Economic Affairs.

Penrose, E.T. (1980), The Theory of the Growth of the Firm (2nd ed.), Basil Blackwell, 1st edition 1959.

Prahalad, C.K. \& Bettis, R.A. (1986), The Dominant Logic: A New Linkage between Diversity and Performance, Strategic Management Journal, Vol.7,pp.485-501

Prokesch, S.E. (1995) Competing on Customer Service, Harvard Business Review, Nov.Dec. pp. 101-112.

Quinn, J.B. (1980), Strategies for Change: Logical Incrementalism, Richard D. Irwin, Inc. 
Sanchez, R. (1995), Strategic Flexibility in Product Competition, Strategic Management Journal, Vol.16,pp. 135-159.

Schendel D. E. \& Hofer, C. W (1979), (Eds.), Strategic Management, A New View of Business Policy and Planning, Little, Brown and Co.

Senge, P. M. (1990), The Fifth Discipline: The Art and Practice of The Learning Organization, Century Business.

Shostack, G.L. (1984), Services Positioning through Structural Change, Journal of Marketing, Vol.51, January, pp.34-43.

Shrivastava, P. (1986), Is Strategic Management Ideological?, Journal of Management, Vol.12,No.3, pp.363-377.

Silvestro, R. (1998), The Manufacturing TQM and Service Quality Literatures:

Synergistic or Conflicting Paradigms, International Journal of Quality and Reliability Management, Vol.15, Issue 3, pp.303-328.

Simon, H. (1957), Administrative Behavior, Macmillan.

Sloan, A.P.Jr. (1963), My Years with General Motors, Doubleday \& Co.

Smircich, L. (1983), Concepts of Culture and Organizational Analysis, Administrative Science Quarterly, Vol.28, pp. 339-358.

Sproull, L.S. (1981), Beliefs in Organizations, In: Nystrom, P.C. and Starbuck, W.H. (eds.), Handbook of Organizational Design, Oxford University Press, pp.166-202.

Stacey, R.D. (1991), The Chaos Frontier, Butterworth-Heinemann.

Stacey, R.D. (1995), The Science of Complexity: An Alternative Perspective for Strategic Change Processes, Strategic Management Journal, Vol.16,pp.477-495.

Stacey, R.D. (2000), Strategic Management and Organisational Dynamics: The Challenge of Complexity, Pearson Education Ltd.

Stauss, B. (1993), Service Problem Deployment: Transformation of Problem Information into Problem Prevention Activities, International Journal of Service Industry

Management, Vol. 4, No. 2, pp. 41-62.

Taylor, F.W. (1911), The Principles of Scientific Management, Harper \& Row.

Venkatesh, A. (1985), Is Marketing Ready for Kuhn?, In: Changing the Course of Marketing, (Eds: Dholakia, N. \& Arndt, J.), JAI Press, Greenwich, pp.45-67.

Weber, M. (1947), The Theory of Social and Economic Organization, Trans. Parsons, T., Free Press.

Weick, K. E. (1995), Sensemaking in Organizations, Sage Publications.

Wernerfelt, B. (1984), A Resource-based View of the Firm, Strategic Management Journal, Vol.5, pp.171-180.

Whittington, R. (1993), What is Strategy and does it matter? Routledge.

Wilson, D.C. (1992), A Strategy of Change, Routledge.

Zeithaml, V.A. \& Bitner M.J. (2000), Services Marketing, $2^{\text {nd }}$. Ed., McGraw-Hill 


\begin{tabular}{|c|c|c|c|}
\hline $\begin{array}{l}\text { Strategy } \\
\text { Paradigms }\end{array}$ & Main Messages for Management & $\begin{array}{c}\text { Advantages for the Management } \\
\text { of Quality }\end{array}$ & $\begin{array}{c}\text { Limitations for the Management } \\
\text { of Quality }\end{array}$ \\
\hline \multicolumn{4}{|c|}{ Rational Paradigms } \\
\hline $\begin{array}{l}\text { Rational } \\
\text { planning }\end{array}$ & $\begin{array}{l}\text { Address risk by analysis, prediction and } \\
\text { planning for the future and be proactive }\end{array}$ & $\begin{array}{l}\text { Effective in relatively complex (detail) and } \\
\text { predictable conditions. Effective for simple } \\
\text { products where standardization is required }\end{array}$ & $\begin{array}{l}\text { Less effective for complex services (e.g. } \\
\text { professional services) and unstable } \\
\text { conditions. Hierarchically imposed } \\
\text { strategies may not be accepted }\end{array}$ \\
\hline Modernist & Control inputs to maximise outputs & $\begin{array}{l}\text { Some control may be necessary for very } \\
\text { standardized situations }\end{array}$ & $\begin{array}{l}\text { Focused on quantity which can have a } \\
\text { negative effect on quality }\end{array}$ \\
\hline Functionalist & $\begin{array}{l}\text { Break down complexity into its constituent } \\
\text { parts }\end{array}$ & $\begin{array}{l}\text { Useful for measurement of constituent } \\
\text { parts of products/service quality }\end{array}$ & $\begin{array}{l}\text { Management may be bogged down in the } \\
\text { minute of what is measurable. Bureaucratic } \\
\text { strategies may only be appropriate for very } \\
\text { standardized situations }\end{array}$ \\
\hline Holistic & $\begin{array}{l}\text { The whole is greater that the sum of the } \\
\text { parts, therefore, obtain a holistic overview. } \\
\text { Develop networks to increase quality }\end{array}$ & $\begin{array}{l}\text { A holistic overview is closer to the } \\
\text { customers' view of quality. Management is } \\
\text { not bogged down in minute detail. } \\
\text { Networks have increased quality in } \\
\text { practice (e.g. car manufacturing) }\end{array}$ & $\begin{array}{l}\text { Lacks detail but this detail may be useful to } \\
\text { highlight specific problems with part of the } \\
\text { product/service quality }\end{array}$ \\
\hline \multicolumn{4}{|c|}{ Developmental Paradigms } \\
\hline $\begin{array}{l}\text { Evolutionary } \\
\text { (Lamarkian) }\end{array}$ & Take a long-term perspective & $\begin{array}{l}\text { Effective for building sustainable quality } \\
\text { advantage }\end{array}$ & Can be too internally focused \\
\hline Process learning & $\begin{array}{l}\text { Develop quality by learning from } \\
\text { processes. }\end{array}$ & $\begin{array}{l}\text { Incremental development is less risky than } \\
\text { creative leaps }\end{array}$ & $\begin{array}{l}\text { Can be too internally focused on small } \\
\text { changes that are not important to customers }\end{array}$ \\
\hline $\begin{array}{l}\text { Resource-based } \\
\text { View }\end{array}$ & $\begin{array}{l}\text { Develop and exploit unique difficult to } \\
\text { imitate quality resources. Competitive } \\
\text { advantage is based on resource specificity }\end{array}$ & $\begin{array}{l}\text { Difficult for competitors to imitate e.g. } \\
\text { quality of design/ innovation and co-- } \\
\text { ordination }\end{array}$ & $\begin{array}{l}\text { Difficult to balance conflicting demands - } \\
\text { exploit existing resources/ develop more } \\
\text { resources }\end{array}$ \\
\hline \multicolumn{4}{|c|}{ Deterministic Paradigms } \\
\hline $\begin{array}{l}\text { Evolutionary } \\
\text { (Darwinian) }\end{array}$ & $\begin{array}{l}\text { Difficult/ impossible to change due to } \\
\text { structural inertia. Do not consider quality } \\
\text { in isolation - Quality myopia }\end{array}$ & $\begin{array}{l}\text { Recognizes the need to consider external } \\
\text { forces and resource specificity }\end{array}$ & $\begin{array}{l}\text { Implications can lead to a passive fatalistic } \\
\text { view of management }\end{array}$ \\
\hline \multicolumn{4}{|c|}{ Probabilistic Paradigms } \\
\hline Ecological & $\begin{array}{l}\text { Quality is a relative concept dependent on } \\
\text { competition. Need to find a niche before } \\
\text { competitors, therefore differentiate and } \\
\text { focus on speed of response to change }\end{array}$ & $\begin{array}{l}\text { Recognizes the business reality of a } \\
\text { dynamic changing environment where } \\
\text { quality also has to continually change }\end{array}$ & $\begin{array}{l}\text { Can lead to cost disadvantages because } \\
\text { differentiation is expensive }\end{array}$ \\
\hline $\begin{array}{l}\text { Process } \\
\text { (Emergent) }\end{array}$ & $\begin{array}{l}\text { Strategy needs to address multiple } \\
\text { conflicting goals and political issues. } \\
\text { Expect modification to strategy. Different } \\
\text { views of quality can be barriers to change. }\end{array}$ & $\begin{array}{l}\text { Effective explanation for political } \\
\text { organizations with barriers to change. } \\
\text { Strategy can take account of organizational } \\
\text { context }\end{array}$ & Difficult to manage emergent issues \\
\hline Game theory & $\begin{array}{l}\text { Follow the quality leader to maintain } \\
\text { equilibrium }\end{array}$ & $\begin{array}{l}\text { Prospect of stable competition with main } \\
\text { competitors }\end{array}$ & $\begin{array}{l}\text { Focused on existing competition but other } \\
\text { competitors can enter the 'game' and } \\
\text { change the rules }\end{array}$ \\
\hline Behavioural & $\begin{array}{l}\text { Difficult to predict successful } \\
\text { products/services and level of quality, } \\
\text { therefore use trial and error strategies using } \\
\text { feedback from customers }\end{array}$ & Highly adapted to customer needs & $\begin{array}{l}\text { Expensive because it requires a large } \\
\text { number of options for customers to choose } \\
\text { the favourites }\end{array}$ \\
\hline Social contextual & $\begin{array}{l}\text { Companies are socially embedded. } \\
\text { Strategy should be studied within the social } \\
\text { context }\end{array}$ & $\begin{array}{l}\text { Socially embedded competitive advantage } \\
\text { is likely to be sustainable }\end{array}$ & $\begin{array}{l}\text { Socially embedded competitive advantage } \\
\text { may not be unique enough }\end{array}$ \\
\hline \multicolumn{4}{|l|}{ Chaos Paradigms } \\
\hline Post-modernist & $\begin{array}{l}\text { Consumers are unpredictable often } \\
\text { subscribing to multiple contradictory value } \\
\text { systems and lifestyles. Symbolic quality } \\
\text { more important than utilitarian quality }\end{array}$ & $\begin{array}{l}\text { Recognizes the importance of symbolic } \\
\text { quality. Symbolic associations of the brand } \\
\text { are difficult for competitors to copy }\end{array}$ & $\begin{array}{l}\text { Brand building is expensive. Symbolic } \\
\text { associations are difficult to study and } \\
\text { measure }\end{array}$ \\
\hline Chaos theory & $\begin{array}{l}\text { The systemic nature of business systems } \\
\text { suggests long-term unpredictability and the } \\
\text { inter-connectedness of quality with other } \\
\text { issues. }\end{array}$ & $\begin{array}{l}\text { Recognizes that quality is inter-connected } \\
\text { with other management issues. Recognizes } \\
\text { the delays and non-linearity of cause and } \\
\text { effect }\end{array}$ & Dealing with systemic problems is difficult \\
\hline
\end{tabular}

Table 1 